\title{
Environmental Justice and Factors that Influence Participation in Tree Planting Programs in Portland, Oregon, U.S.
}

\author{
Geoffrey H. Donovan and John Mills
}

\begin{abstract}
Many cities have policies encouraging homeowners to plant trees. For these policies to be effective, it is important to understand what motivates a homeowner's tree-planting decision. Researchers address this question by identifying variables that influence participation in a tree-planting program in Portland, Oregon, U.S. According to the study, homeowners with street trees, and those living in older homes, are more likely to participate in the local program. Homeowners who had owned their homes for longer, and those who live in census-block groups with lower high-school graduation rates, are less likely to participate in the program. Results suggest that tree-planting programs may inadvertently exacerbate environmental inequality. Key Words. Census; Demographics; Education; Environmental Justice; Income; Oregon; Portland; Race; Urban Forestry.
\end{abstract}

In the last 25 years, research has found that trees provide a diverse range of benefits to urban residents (Ulrich 1984; Akbari and Taha 1992; Kuo and Sullivan 2001; McPherson et al. 2005; Nowak et al. 2006; Donovan and Butry 2010), which has encouraged many cities to adopt ambitious tree-planting goals. Indeed, of the ten largest cities in the United States, nine have explicit targets for increasing the size of their urban forests-expressed as number of new trees planted. For example, New York City, New York, is committed to planting 1 million trees by 2017 (Million Trees NYC 2012) and Phoenix, Arizona, has a goal of $25 \%$ canopy cover by 2030 (City of Phoenix 2010). However, in most cities, these goals cannot be achieved by only planting trees in parks, at schools, or other public spaces (Karps 2007; Greene et al. 2011). Cities must also rely on homeowners to plant trees on private property. To effectively encourage homeowners to plant trees, it is important to understand why homeowners plant trees and to identify the barriers that prevent them from doing so.

It is also important to know what motivates people to participate in tree-planting programs, as these programs can have unintended environmentaljustice implications. Environmental justice is the ethical principle that environmental benefits and burdens should be equitably distributed. More formally, the U.S. Environmental Protection Agency defines environmental justice as, "The fair treatment and meaningful involvement of all people regardless of race, color, sex, national origin, or income with respect to the development, implementation, and enforcement of environmental laws, regulations, and policies" (U.S. Environmental Protection Agency 2012). In the current study, researchers examine whether some demographic groups (e.g., those with higher incomes) are more likely to participate in, and benefit from, a tree-planting program.

Environmental justice is an important issue in urban forestry, as research has shown that trees provide a broad range of benefits, including increased house price (Anderson and Cordell 1988; Culp 2008), reduced energy use (Akbari et al. 1997; Donovan and Butry 2009), reduced crime (Kuo and Sullivan 2001; Troy et al. 2012), improved air quality (Nowak et al. 2006), and improved public health (Donovan et al. 2011; Lovasi et al. 2008; Donovan et al. 2013).

Although no studies have examined the environmental-justice consequences of tree-planting programs, several studies have shown that more affluent neighborhoods tend to have more natural amenities or greater species diversity (Heynen and Lindsey 
2003; Hope et al. 2003; Heynen et al. 2006; Szantoi et al. 2012). If residents of affluent neighborhoods are also more likely to participate in tree-planting programs than residents of less affluent neighborhoods, then these programs have the potential to exacerbate environmental injustice. Conversely, if residents of poorer neighborhoods are more likely to participate in a tree-planting program, then the program could be used to reduce environmental injustice.

Only two previous studies were found to have investigated the reasons why urban residents plant trees. Summit and McPherson (1998) administered a survey to 133 residents of Sacramento, California, U.S., about past tree planting and maintenance. In addition, they took detailed inventories of existing trees and identified the potential for new plantings. The authors found that residents were most likely to plant trees soon after they moved to a house. In addition, aesthetics and shade were identified as the main reasons for tree planting. The authors collected detailed information on existing trees as well as house and lot size. They did not, however, investigate the effect of demographics (except age) on the tree-planting decision.

In contrast to Summit and McPherson (1998), Greene et al. (2011) focused on how demographics influenced participation in a tree-planting program in Toronto, Ontario, Canada. They found that the number of single detached dwellings, immigration status, income, house age, and percent of females employed all influenced participation in the program, although results varied across neighborhoods. The authors did not have access to household-level data. Rather, their unit of observation was a census tract $(n=490)$. The authors were careful to point out that their aggregate results may not apply at the household level. The coarse scale of the study also meant that they were unable to account for the effect of existing trees, planting spaces, house size, and lot size, among other criteria.

The authors build on these two studies by investigating why urban residents in Portland, Oregon, U.S., agree to participate in a tree planting program. Detailed household-level data were incorporated, as well as demographic data at the census block-group level, into a random-effects regression model. Formally, the study authors hypothesize that attributes of a house, the number and size of existing trees, the number of planting spaces, characteristics of the canvasser, and the demographic makeup of a neighborhood all influence the likelihood that a household agrees to participate in a tree-planting program.

\section{DATA AND STUDY AREA}

Portland is located in northwest Oregon near the confluence of the Willamette and Columbia rivers. The city has a population of 584,000, while the Portland metropolitan area has population of 2,260,000. Currently, $26 \%$ of the city is covered by tree canopy, but the city wants to increase canopy cover to 33\% (Karps 2007). This goal cannot be met solely by planting trees on public land; the city must also rely on private landowners to plant trees. As part of this process, the city has been canvassing residents about their willingness to plant a tree in the parking strip fronting their home. If residents agreed, then trees were provided at reduced cost and planted during a neighborhood tree-planting day overseen by a local non-profit called Friends of Trees.

In Portland, parking strips are public land (i.e., right-of-way), but the adjacent property owner is responsible for planting and maintaining trees in the parking strip. In addition, a permit is required to plant or remove a tree in the parking strip.

Between June 10, 2010, and August 10, 2011, the City of Portland canvassed 51,885 homes in Eastside Portland (east of the Willamette River). The city focused on Eastside Portland because it has 20\% canopy cover, whereas Westside Portland has 55\% canopy cover (this includes the 2,000 hectares of Forest Park).

In addition to promoting a tree-planting program, canvassers recorded data on the number of trees currently in the parking strip fronting a house, the number of unfilled planting spaces, width of the parking strip, and the presence of overhead power lines. Canvassers only visited houses that had at least one available planting space in the parking strip fronting the house.

A priori, canvassers were not expected to be equally effective at convincing residents to participate in the tree-planting program. Therefore, 11 dummy variables were used to identify canvassers. Ten of these dummy variables denoted an individual, while the eleventh denoted a group of canvassers who had individually visited only a handful of houses. In addition to these canvasser dummy variables, a dummy variable was created to denote a canvasser's gender. 
Researchers hypothesized that the number and size of existing trees might influence a homeowner's decision to plant a new tree. Therefore, using imagery from Google Earth, the crown area of street trees fronting houses was hand measured. The average of two diameter measurements was used to estimate the canopy contribution of each tree. Measuring canopy cover by hand is a time-consuming process, and it would have been prohibitively costly to measure the trees outside all 51,885 houses the City of Portland visited. The project budget allowed researchers to measure the trees outside 4,428 houses randomly drawn from the larger sample (Figure 1).

Using addresses, the 4,428 houses in the sample were matched with data from the Multnomah County Tax Assessors Office on house size, lot size, assessed value, house age, and the year of most recent sale. Unfortunately, researchers did not have access to demographic data at the house- hold level. Therefore, American Community Survey data were used at the block-group level. A GIS layer of block-group boundaries was used to assign demographic data to each address in the sample.

The American Community Survey is an ongoing statistical survey by the U.S. Census Bureau, sent to approximately 250,000 addresses monthly. A wide range of demographic variables that described housing occupancy were considered (e.g., percent of houses that are owner occupied), including family structure (e.g., percent of households with a married couple), race (e.g., percent white), education (e.g., percent without a high-school diploma), and income (e.g., per capita income).

The sample was not spread evenly across Portland (Figure 1). To determine whether the sample was representative of the whole city, researchers compared selected demographic characteristics of the 221 census-block group that contained at least

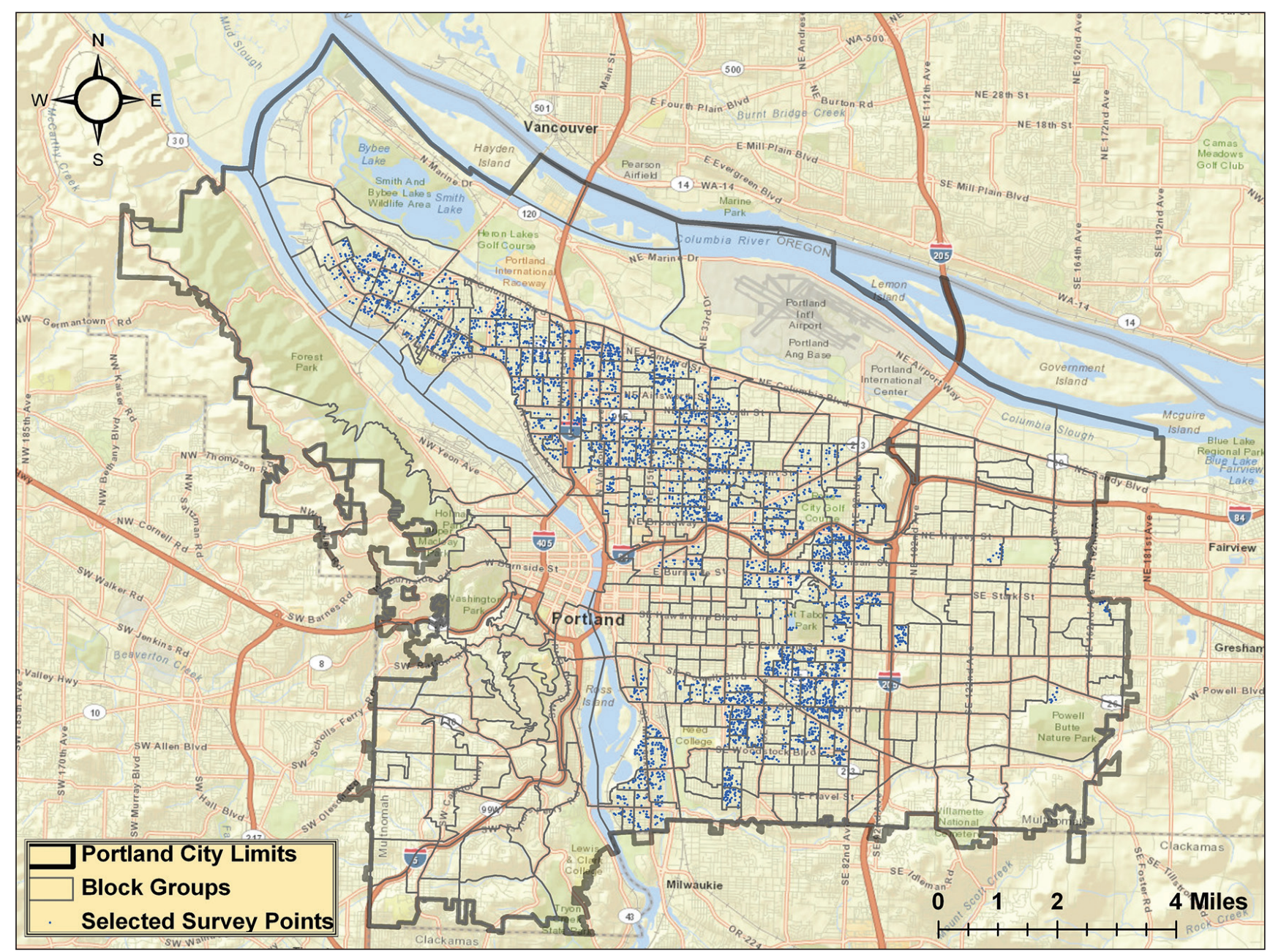

Figure 1. Distribution of sample points $(n=4,428)$ and block groups $(n=410)$. 
Table 1. Comparison of selected block-group demographics for study sample and City of Portland (SD = Standard Deviation). Currency is listed in U.S. dollars.

\begin{tabular}{lll}
\hline Variable & Sample mean (SD) & City mean (SD) \\
\hline Percent owner occupied & $64(19)$ & $63(20)$ \\
Percent non-Hispanic white & $79(15)$ & $80(14)$ \\
Percent over 25 without high-school diploma & $9(8)$ & $10(9)$ \\
Percent households making less than \$50K & $49(17)$ & $49(18)$ \\
\hline
\end{tabular}

one sample point to the demographic characteristics of the whole city (410 block groups). For this comparison, 33 block groups were excluded because they were either primarily industrial or commercial (less than 50 households) or more than 50 percent of a block group fell outside the Portland city limits (Table 1). There were no statistically significant demographic differences between the sample and the whole city. This was true of all demographic variables, not just those presented in Table 1 .

\section{STATISTICAL ANALYSIS}

In classical regression, it is assumed that observations are independent. Unfortunately, the current data violates this assumption. Specifically, observations in the same census block group are more alike than observations in different block groups. In addition, the dependent variable is binary: 1 if a resident agreed to participate in a tree-planting program and 0 otherwise. Binary response data with intra block-group dependence can be accommodated using a fixed-effects or a random-effects logit model:

$$
Y_{i, j}=\alpha+\beta X_{i, j}+v_{i}
$$

where $Y_{i, j}$ denotes the ith survey response in the $j$ th census block ( 1 if a respondent agreed to participate in the tree-planting program and 0 otherwise), $X_{i, j}$ is a vector of independent variables, $v_{i}$ is the block-group specific residual or intercept, and $\alpha$ and $\beta$ are coefficients to be estimated in the regression step. This model structure allows researchers to include independent variables that vary at the parcel level (e.g., number of street trees) and at the blockgroup level (e.g., high-school graduation rate).

A fixed-effects model adds a block-group specific intercept, whereas a random-effects model adds a block-group specific residual (one is a model parameter, whereas the other is a random variable). The intercept or residual serves the same purpose: if accounts for block-specific effects that are not explained by the independent variables. For example, respondents in a particular block group may be more likely to participate in a tree-planting program, because traffic noise is a problem in that block group. The intercept or residual would account for this difference.

A Hausman specification test was used to choose between a fixed-effects and a random-effects model. The null hypothesis of the Hausman test assumes that there is no systematic difference between model coefficients estimated using fixed-effects versus random-effects estimators (Greene 2000). If the null hypothesis holds, both estimators are consistent, but only the random-effects estimator is efficient. If the null hypothesis is rejected, the random-effects estimator is inconsistent. In the case of the current, the $P$-value for the Hausman test was 0.0546 , and so the study authors narrowly failed to reject the null hypothesis using the customary $P$-value threshold of 0.05 , and, therefore, use the random-effects estimator for the following analysis. Given the closeness of rejecting the null hypothesis, it is possible that the coefficient estimates are inconsistent. However, one can draw comfort from the fact that both the random- and fixed-effects estimators are unbiased.

Variables were selected for inclusion in the final model using iterative backwards selection. Analysis began with the inclusion of a complete list of candidate variables, although a variance-covariance matrix was used to avoid including highly collinear combinations of variables in the same model. For example, percent of residents with a college degree and percent without a high-school diploma have a correlation coefficient of -0.66 , and so were not included in the same model. All variables with a p-value of greater than 0.8 were then dropped. This process was repeated with progressively lower $P$-value thresholds of $0.6,0.4,0.2$, and 0.1 . The only exception to this selection criterion was groups of dummy variables (e.g., canvasser dummy variables). If one dummy variable from a group was significant, then the entire group was retained. Because highly correlated combinations of variables in 
the same model couldn't be included, this process was somewhat iterative. For example, researchers went through the selection process, including percent with a college degree, and then repeated the process with percent with a high-school diploma. The variable with the lowest $P$-value was retained.

\section{RESULTS}

Table 2 shows that some canvassers were more successful at convincing people to participate in the tree-planting program than others. Specifically, canvassers with initials B.B., M.R.O., and N.U. were significantly more successful than the omitted group, which was a composite group made up of several canvassers who each only visited a few houses. All three successful canvassers were women (the letters $\mathrm{M}$ and $\mathrm{F}$ in parentheses denote gender), and so the model was re-estimated using a single dummy variable denoting gender in place of the ten canvasser dummy variables. The gender dummy was significant, which indicates that overall female canvassers were more effective than male canvassers. However, the explanatory power of the gender-only model was lower $($ AIC $=4935)$ than the full model (AIC $=4900)$, which suggests that gender does not fully explain the different canvasser success rates. Akaike Information Criterion (AIC) is a goodness of fit measure that can be used to compare non-nested non-linear models; as with the equation, $\mathrm{AIC}=2 \cdot \mathrm{k}-2 \cdot \operatorname{Ln}(\mathrm{L})$, where $\mathrm{k}$ is the number of model parameters and $\mathrm{L}$ is the maximized value of the likelihood function.

It was found that people who already have street trees are more likely to agree to plant more trees, while the number of empty planting spots was not significant in the model. This suggests that available space is not a significant barrier to participation in the tree-planting program. Recall that each house has at least one empty planting space. It appears that Portland's tree-planting program will encourage tree planting where trees are already present, but the program may be less effective at encouraging tree planting in places with few trees.

The coefficient on house age was positive, indicating that people who live in older homes are more likely to plant a tree. This may be because people who have a preference for trees also prefer older homes or established neighborhoods. It is also possible that home age is, at least partially, a proxy for the effect of neighborhood that is not being picked up by the random effects.

Consistent with past research (Summit and McPherson 1998), researchers of the current study found that people who had lived in a house longer were less likely to agree to plant a tree. This suggests that tree-planting program could fruitfully focus on newer homeowners.

Finally, people who lived in census block groups with lower high-school graduation rates were less likely to agree to plant a tree. On average, in this sample, $9.5 \%$ of adults over 25 didn't graduate high school. The highest failed-tograduate rate was $41 \%$. This result has significant environmental-justice implications, as census blocks with low high-school graduation rates also tend to have lower median income and more non-white residents. In the sample, the correlation coefficient between percent with a college

Table 2. Random effects regression results of the covariates that influence the probability of participation in a treeplanting program (number of groups $=222$, number of observations $=4,428$ ).

\begin{tabular}{llll}
\hline Variable & Coefficient & Standard error & $P$-value \\
\hline Intercept & -0.790 & 0.315 & 0.012 \\
Canvasser BB (F) & 0.656 & 0.300 & 0.029 \\
Canvasser BL (M) & -0.0602 & 0.310 & 0.846 \\
Canvasser BT (M) & -0.0237 & 0.310 & 0.939 \\
Canvasser JM (M) & 0.331 & 0.302 & 0.273 \\
Canvasser KC (F) & 0.481 & 0.307 & 0.117 \\
Canvasser MRO (F) & 0.759 & 0.310 & 0.014 \\
Canvasser MD (M) & 0.179 & 0.311 & 0.566 \\
Canvasser MC (F) & -0.282 & 0.328 & 0.388 \\
Canvasser NU (F) & 0.903 & 0.303 & 0.003 \\
Canvasser SK (F) & 0.482 & 0.303 & 0.112 \\
Number of street trees & 0.120 & 0.0525 & 0.023 \\
House age & 0.00640 & 0.0162 & $<0.001$ \\
Years in house & -0.0420 & 0.00217 & $<0.001$ \\
Percent over 25 without & -1.08 & 0.495 & 0.029 \\
high-school diploma & & &
\end{tabular}


degree and percent of households with an income of less than USD $\$ 50,000$ is -0.63 . The correlation coefficient between percent white and percent without a high-school diploma is -0.49 .

There are a number of possible reasons why residents of census blocks with lower education levels are less willing to plant a tree. Young trees in Portland require watering in hot dry summer months, which represents an immediate investment of time and money. The benefits trees provide take years to realize in terms of shade, value to the home, and other ecosystem services. Census block groups associated with less education and lower incomes are also correlated with more renters and higher rates of crime. Given that trees are a long-term investment; this environment and more immediate needs may make residents reluctant to plant a tree.

\section{DISCUSSION}

These findings raise some difficult issues about tree-planting programs. This research presents a dilemma for the City of Portland in particular. A tree-planting program will tend to be more successful in areas of higher socioeconomic status. However, this success will have environmental justice implications, as areas with higher socioeconomic status tend to have more, and better maintained, environmental amenities. However, if the City concentrated their efforts in neighborhoods with lower socioeconomic status in an attempt to alleviate environmental inequalities, then overall it is likely that fewer residents would agree to plant trees, which would result in fewer tree benefits for the whole city.

The results do not provide direct insight into why residents of census block groups with lower education levels are less likely to participate in a treeplanting program. Broadly, residents with lower socioeconomic status may have different environmental preferences, or canvassers may have done a particularly poor job of convincing lower socioeconomic status residents to plant trees. Beyond gender, there wasn't any demographic data available on the canvassers. However, those in charge of the program remember canvassers as being predominantly young, white, and educated. Furthermore, past research has shown that, across a range of social situations, people respond more positively to those with a similar demographic profile (Durrant et al. 2010). Therefore, canvassers may simply have been more successful in neighborhoods where they more closely matched the demographics of residents.

Although the demography of canvassers may partially explain the results, it is likely that residents of census blocks with lower education levels also have different environmental preferences. For example, people of lower socioeconomic status are more likely to be renters and move more frequently (Masnick 2002). Both these reasons make an investment in a tree less appealing.

It is also possible that trees provide different benefits in neighborhoods with lower socioeconomic status. For example, Troy and Grove (2008) found that in wealthy neighborhoods of Baltimore, Maryland, U.S., houses nearer to parks had higher sale prices. In contrast, houses in poorer neighborhoods sold for less, if they were close to a park. The authors speculate that parks may attract crime in poorer neighborhoods. This explanation is bolstered by a later study (Troy et al. 2012), which found that higher tree-canopy cover was associated with lower crime in wealthier neighborhoods but was associated with higher crime in poorer neighborhoods.

These studies suggest that residents of lower socioeconomic status neighborhoods may be responding rationally when they decline to participate in a treeplanting program. Although some of the benefits of trees may be lower in poorer neighborhoods, other benefits (e.g., air quality and stormwater mitigation) are unaltered. However, some of these benefits are experienced by residents in other neighborhoods (e.g., reductions in stormwater runoff benefit a whole city or region). Therefore, tree-planting programs should be tailored to specific neighborhoods. Canvassers should be selected with care, and it may be appropriate to offer greater incentives to residents of poorer neighborhoods. Specifically, it may be fruitful to hire canvassers from the neighborhoods where a program is to be implemented, and a sliding scale could be used for tree costs.

This study has several limitations. Researchers were forced to rely on demographic data at the census block group level, as they didn't have access to data at the household level. Therefore, the results do not necessarily apply to a particular individual. In addition, the demographic characteristics of canvassers are not known. It would have been interest- 
ing to see whether homeowners were more readily convinced to plant a tree by a canvasser with similar demographics. If so, then carefully matching a canvasser to a neighborhood might improve success rates in minority neighborhoods. Finally, the results should be applied to other cities with care. Although these findings are consistent with studies conducted in Sacramento and Toronto, to some degree, these resultsareanartifact of theidiosyncrasies of Portland.

\section{LITERATURE CITED}

Akbari, H., D.M. Kurn, S.E. Bretz, and J.W. Hanford. 1997. Peak power and cooling energy savings of shade trees. Energy and Buildings 25:139-148.

Akbari, H., and H. Taha. 1992. The impact of trees and white surfaces on residential heating and cooling energy use in four Canadian cities. Energy 17:141-149.

Anderson, L., and H.K. Cordell. 1988. Influence of trees on residential property values in Athens Georgia (U.S.A.): A survey based on actual sales prices. Landscape and Urban Planning 15:153-164.

City of Phoenix. 2010. Maryvale Village Planning Committee. Accessed on April 23, 2013. <http://phoenix.gov/district5/ d5mvpcr.html>

Culp, R.P. 2008. Predicting days on the market: The influence of environmental and home attributes. New York Economic Review:70-82.

Donovan, G.H., and D.T. Butry. 2009. The value of shade: Estimating the effect of urban trees on summertime electricity use. Energy and Buildings 41:662-668.

Donovan, G.H., and D.T. Butry. 2010. Trees in the city: Valuing street trees in Portland, Oregon. Landscape and Urban Planning 94:77-83.

Donovan, G.H., D.T. Butry, Y.L. Michael, J.P. Prestemon, D. Gatziolis, and M.Y. Mao. 2013. The relationship between trees and health: Evidence from the spread of the emerald ash borer. American Journal of Preventive Medicine 44:139-145.

Donovan, G.H., Y.L. Michael, D.T. Butry, A.D. Sullivan, and J.M. Chase. 2011. Urban trees and the risk of poor birth outcomes. Health and Place 17:390-393.

Durrant, G.B., R.M. Groves, L. Staetsky, and F. Steele. 2010. Effects of Interviewer Attitudes and Behaviors on Refusal in Household Surveys. Public Opinion Quarterly 74:1-36.

Greene, C.S., A.A. Millward, and B. Ceh. 2011. Who is likely to plant a tree? The use of public socio-demographic data to characterize client participants in a private urban forestation program. Urban Forestry \& Urban Greening 10:29-38.

Greene, W.H. 2000. Econometric Analysis, Fourth Edition. PrenticeHall, Upper Saddle River, New Jersey, U.S.

Heynen, N., H.A. Perkins, and P. Roy. 2006. The political ecology of uneven urban green space: The impact of political economy on race and ethnicity in producing environmental inequality in Milwaukee. Urban Affairs Review 42:3-25.
Heynen, N.C., and G. Lindsey. 2003. Correlates of urban forest canopy cover: Implications for local public works. Public Works Management and Policy 8:33-47.

Hope, D., C. Gries, W. Zhu, W.F. Fagan, C.L. Redman, N.B. Grimm, A.L. Nelson, C. Martin, and A. Kinzig. 2003. Socioeconomics drive urban plant diversity. Proceedings of the National Academy of Sciences, USA. 100:8788-8792.

Karps, J. 2007. Portland's urban forest canopy: Assessment and public tree evaluation. Portland Parks and Recreation, Portland, Oregon. p. 43

Kuo, F.E., and W.C. Sullivan. 2001. Environment and crime in the inner city: Does vegetation reduce crime? Environment and Behavior 33:343-367.

Lovasi, G.S., J.W. Quinn, K.M. Neckerman, M.S. Perzanowski, and A. Rundle. 2008. Children living in areas with more street trees have lower prevalence of asthma. Journal of Epidemiology \& Community Health 62:647-649.

Masnick, G.S. 2002. The new demographics of housing. Housing Policy Debate 13:275-321.

McPherson, E.G., J.R. Simpson, P.J. Peper, S.E. Maco, and Q. Xiao. 2005. Municipal forest benefits and costs in five U.S. cities. Journal of Forestry 103:411-416.

Million Trees NYC. 2012. About million trees NYC. Accessed 04/23/2013. <www.milliontreesnyc.org/html/about/about.shtml>

Nowak, D.J., D.E. Crane, and J.C. Stevens. 2006. Air pollution removal by urban trees and shrubs in the United States. Urban Forestry \& Urban Greening 4:155-123.

Summit, J., and E.G. McPherson. 1998. Residential tree planting and care: A study of attitudes and behavior in Sacramento, California. Journal of Arboriculture 24:89-96.

Szantoi, Z., F. Escobedo, J. Wagner, J. Rodriguez, and S. Smith. 2012. Socioeconomic factors and urban tree cover policies in a subtropical urban forest. GIScience and Remote Sensing 49:428-449.

Troy, A., and J.M. Grove. 2008. Property values, parks, and crime: A hedonic analysis in Baltimore, MD. Landscape and Urban Planning 87:233-245.

Troy, A., J. Morgan Grove, and J. O’Neil-Dunne. 2012. The relationship between tree canopy and crime rates across an urban-rural gradient in the greater Baltimore region. Landscape \& Urban Planning 106:262-270.

Ulrich, R.S. 1984. View through a window may influence recovery from surgery. Science 224:420-421.

U.S. Environmental Protection Agency. 2012. Environmental Justice Program and Civil Rights. Accessed on April 23, 2013. $<$ www.epa.gov/region1/ej/>

Geoffrey H. Donovan (corresponding author)

USDA Forest Service

PNW Research Station

Portland, Oregon, U.S.

John Mills

USDA Forest Service

PNW Research Station

Portland, Oregon, U.S. 
Zusammenfassung. Viele Städte haben Verordnungen, die Hauseigentümer ermutigt, Bäume zu pflanzen. Damit diese Verordnungen effektiv sind, ist es notwendig zu verstehen, was einen Hausbesitzer motiviert, Bäume zu pflanzen. Forscher stellten diese Frage, indem sie Variablen identifizierten, die die Teilnahme an einem Baumpflanzprogramm in Portland, Oregon, U.S.A. beeinflussten. Es kam heraus, dass Hauseigentümer mit Straßenbäumen und solche, die in älteren Häusern leben, sich eher an Programmen beteiligen. Hauseigentümer, die ihr Haus schon länger besitzen und solche, die in Wohnblockgruppen wohnen und niedrige Schulabschlüsse haben, nehmen eher nicht an solchen Programmen teil. Die Ergebnisse verdeutlichen, dass Baumpflanzprogramme ungewollt das ökologische Ungleichgewicht verstärken.

Resumen. Muchas ciudades tienen políticas que alientan a los propietarios a plantar árboles. Para que estas políticas sean eficaces es importante entender lo que motiva la decisión del propietario. Los investigadores abordaron esta cuestión mediante la identificación de las variables que influyen en la participación en un programa de plantación de árboles en Portland, Oregon, EE.UU. Se encontró que los propietarios de viviendas con árboles en las calles, y los que viven en las casas antiguas, eran más propensos a participar en el programa. Los propietarios por más tiempo y los que vivían en bloques, con niveles de graduación secundaria inferior, fueron menos propensos a participar en los programas. Los resultados sugieren que los programas de plantación de árboles pueden inadvertidamente exacerbar la desigualdad ambiental. 